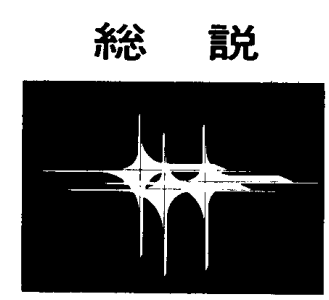

\title{
B 型肝炎の感染防止対策
}

野口照 義*

院内感染防止上の重要な課題の一つとして B 型肝炎ウィルスの感染防止対策がある. B 型肝 炎の感染予防対策といっても特別なものではな $く$, 通常の感染症と同様感染源, 感染経路, 感 受性体それぞれに対する対策であるといえる。 従ってB型肝炎の感染予防対策は, 一般的なウ イルス感染対策と同様に, B型肝炎を正しく理 解し, その感染経路を適切に遮断し, 効果的な 滅菌, 消毒操作を的確に履行することなど, 一 般の基本的感染予防対策を着実に行なうことに より充分その感染予防効果をあげることが出来 るものである.必要以上の恐怖心を抱いたり, 神経質になることなく, 一般感染症疾患々者と 同様に $\mathrm{HB}_{\mathrm{S}}$ 抗原陽性患者に接し，適切な 説明 や注意指導を与えるためにも，先ず $\mathrm{B}$ 型肝炎の 特徵を把握することが大切である.

\section{B 型肝炎}

B 型肝炎ウイルスの感染は, 基本的には血液 を介した非経口的な B 型肝炎ウイルスの感染に よるものであるが，そのほか樰液などの体液を 介した感染や経口的感染もあるといわれている. その主なる感染経路は, 輸血, 血液製品の使用, 人工透析時などのほか母児間感染が注目されて いる. 医療従事者一の感染もまた，人工透析， 輸血, 手術, 産科, 検査などの各部門でその危 険性が高い。

B型肝炎をおこす B 型肝炎ウィルスは，直径 約 $42 \mathrm{~nm}(42 \times 1 / 1,000,000 \mathrm{~mm})$ の粒子で, こ の内部に直径約 $27 \mathrm{~nm} の$ 心 (core) を有する.

* 厂葉県救急医䝤センター所鼓
この粒子の芯に $\mathrm{HB}_{\mathrm{C}}$ 抗原, 外被に $\mathrm{HB}_{\mathrm{S}}$ 抗原の

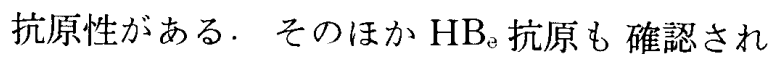
ている.

B型肝炎の感染には，急性感染のほかに， 6 カ月以上繰返して血中 $\mathrm{HB}_{\mathrm{S}}$ 抗原が持続的に陽 性である持続感染（carrier state）となり易い 特徴がある. 潜伏期は，一般的に $1 \sim 6$ 力月位. と長く, その期間は感染した肝炎ウィルスの量 が多ければ短かく, 少なければ長く, 感染した ウィルスの量と逆の相関々係を呈するとも考え られている。

血中 $\mathrm{HB}_{\mathrm{s}}$ 抗原は, この潜伏期中にウィルス の感染量に関係して感染後 $3 \sim 12$ 週間で, また 発症前 $2 \sim 8$ 週間位に出現する. $\mathrm{HB}_{\mathrm{S}}$ 抗 原陽 性の期間は，普通急性期の間持続的に検出され， 回復期に血中から消失する. 短かい場合は数日 の場合もあるが，数力月に亘り陽性の症例もあ る. 成人の約 $5 \sim 10 \%$ が数年に亘って陽性のこ ともあるとの報告も見られる。

血中抗 HBs 抗体は, 通常 HBs 抗原消失後に 検出され，抗体価も低く，発症後 6 力月以後に 出現することが多い，抗 HBs 抗体の出現は， 云うまでもなく感染に対する兔疫を示すもので ある。

$\mathrm{HBs}$ 抗原血中出現時期にほぼ一致して $\mathrm{HB}_{\mathrm{e}}$ 抗原の検出されるものは, 最も感染性が高く逆 に抗 $\mathrm{HB}_{\mathrm{\theta}}$ 抗体が検出される血液 (HBs 抗原陽 性でも)では感染性が低く，まず感染性がない ものと考えられている。

\section{II 一般的対策}

\section{II - 1 HBs 抗原, 抗体検查の実施}


B型肝炎ウィルスの感染予防上最も基本的な ことは，患者が HBs 抗原陽性であることを正 確に認識することである.このためには，少な くとも全ての入院患者について HBs 抗原, 抗 体の検查を施行し，HBs 抗原陽性患者を，医療 従事者にも確実にわかるような適切な方法や手 段をとると同時に, 患者に当人の血液, 体液が 他人の皮膚や粘膜に触れない上うに注意し, 場 合によっては肝炎を惹起させる危険性のあるこ とを教育する必要がある。

患者血中 HBs 抗原検查の実施状況は，昭 和 51 年秋の調查で, 国立大学附属病院 28 施設中 6 施設 (21.4\%) が HBs 抗原の検査を施行して おり，翌52年秋の調查では，31施設中 20 施設 (64.5\%) と検查をしている施設が有意に増加 しておうり，現時点では，HBs 抗原に関する限 り全施設で施行されているものと思われる. 同 じく昭和52年秋の $\mathrm{HB}_{\mathrm{e}}$ 抗原検査実施の調 查で は，31施設中 5 施設 $(16.1 \%)$ で実施されてい た.

HBs 抗体検査の実施状況は, 昭和51年秋の上 述施設の調查で， 28 施設中 5 施設 $(17.9 \%)$, 翌 昭和 52 年に 31 施設中 16 施設 $(51.6 \%)$ と有意に 検查実施施設が増加し, HBe 抗体についても 31 施設中 5 施設 $(16.1 \%)$ で実施されていた.

$\mathrm{HBs}$ 抗原陽性率は, 千葉大学附属病院手術 部での昭和50年 8 月より 51 年 7 月迄の 1 年間の 全手術症例 4108例中, 術前に HBs 抗原検査を 施行した3328例 $(81.0 \%)$ 中104例 $(2.5 \%)$ が 陽性であり，日本人一般健康人の HBs 抗原陽 性率と有意の差がなかった. 他方肝胆道系の手 術患者 218 例 (全手術症例の $5.3 \%$ ) において も, HBs 抗原陽性率は 6 例 (2.8\%) であった が，肝疾患々者で腹腔鏡や肝生検を施行した 88 例中16例 (18.2\%) に血中 HBs 抗原が陽性で有 意に高率であった. 昭和54年の千葉県がんセン タ一手術例上り男性 500 , 女性 500 の計 1000 例 を無差別抽出した調査では, HBs 抗原陽性率 が全体で $1.8 \%$, 男性 $2.0 \%$, 女性 $1.6 \%$ で男 女間に統計的に有意の差はなかったが，年令別 ではその陽性率が，29歳以下で 4.4\%，30 50 歳で $2.6 \%, 60$ 歳以上で $0 \%$ と加令と共に統計 的に有意に減少した. HBs 抗体の陽性率は, 全
体で $16.2 \%$ で男性 $17.6 \%$ ，女性 $14.8 \%$ と男女間 に有意の差を認めなかった. 年令別では 29 歳以 下で，10\%，30 59歳で16.2\%，60歳以上で $17.0 \%$ と加令と共に増加の傾向を認めたが統計 的に有意の差は認めなかった。

\section{II-2 患者の血液, 検査物, 分泌物, 排泄物などへの対策}

B 型肝炎ウィルスで污染されているこれらの もので，周囲を污染しないように極力注意する ことが原則であり基本である。このためには， これらを取り扱ら場合に，これらのものを入れ た容器になんらかの目印をつけて, 医療従事者 にHBs 抗原陽性者のものであることを認識さ せると共に，取り扱い者自身にも注意を喚起さ せる.また直接これらのものを操作処理する場 合は, 出来ればディスポーザブルの手袋を着用 し，必要によっては予防衣も着用する. 特に手 指に創傷のある場合は，充分な注意と手袋の使 用は不可久である.

\section{II-3 患者血液などで直接污染される 医療材料などへの対策}

これらは可能な限りディスポーザブルのもの を利用し，使用後はビニール袋などに入れ周囲 への污染をさけながら焼却する。例えば直接血 液で污染される手術衣, 手術用りネン類なども 出来るだけディスポーザブルが望ましい，

焼却不能で廃棄する場合は, 感染源とならぬ ようオートクレーブまたは薬液浸漬などの滅菌, 消毒処理後に廃裹する.

ディスポーザブル以外で再使用するものは, 適確な滅菌, 消毒処理後平常の取り扱いとする。 例えば血液で污染された布類は, 新鮮強次亜塩 素酸ソーダ溶液に 1 時間以上浸漬後水洗し, オ ートクレーブ後平常扱いとする.

\section{II-4 室, 壁, ベッド手術台などへの対策}

室, 壁, 床などは, $0.5 \%$ 次帚塩素酸ソーダ で清拭する：とくに患者の血液で直接污染され た部位は， $1.0 \%$ 次亜塩素酸ソーダで念入りに 清拭する.手術台, ベッドなどの金属性の部分

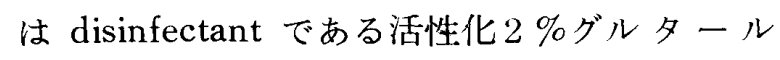
アルデヒドで清拭する・室全体が著るしく污染 された場合は，これら上述溶液による噴霧ある いはホルマリンガスによる消毒を行なうことも 
ある。

\section{II - 5 注射針などへの対策}

患者に使用した注射針など鋭利な小物による 医療従事者の事故が以外に多いので注意を要す る・注射針などは，使用後キャップをすること による事故もあるので，むしろキャップをする ことなくそのまま，別途消毒薬を入れた広口の 瓶などを用意して，そこに值接入れてまとめて 処理した方が事故が少ない。

\section{II - 6 手指消毒の励行}

医療従事者のみならず，患者も流水による手 洗いの実行，必要によっては0.1〜0.5\%次亜塩 素酸ソーダ溶液で消毒後水洗いをする。

\section{III 滅菌，消毒法}

滅菌消毒法としては，一般ウィルスに対する それと大体同様で，被隇菌消毒物により次にあ げるような各種の方法が適宜用いられる。

直接 HBs 抗原陽性の血液で活染された手術 器具特に攝子や鉗子類などの鉣性小物類は，そ のまま特別製の袋にまとめて入れ，袋ごとウオ ジャーステリライザーに入れることにより，周 井への污染もなく便利に隇菌出来て理想的であ る. 最も信頼性の高い滅菌方法は，才一トクレ ーブによるもので，通常 $121^{\circ} \mathrm{C}$ で15 20分閒, $132^{\circ} \mathrm{C}$ で $10 \sim 15$ 分間の条件で実施されている. その他 $170^{\circ} \mathrm{C}$ で 2 時間以上の乾熱隇菌，ディス ポーザブル製品の焼却など物理的な熱処理によ る方法がある．また物理的手段の一つに煮沸が あるが，これは他に適切な方法がない場合に， $98^{\circ} \mathrm{C}$ 以上で 30分間 以上の条件で利用されるこ ともある。焼却を除いた上述の方法は，いずれ も被滅菌消毒物が耐熱性のもののみ対象となり， ウォシャーステリライザー以外の方法に際し, 被滅菌物に多量の血液が付着していると，被滅 菌物に血液が凝固付着して金属類では鈙を生じ 使用不能となることもあるので, その前に適切 な消毒剤による前処置後水洗して熱処理すべき である。

その他化学的な消毒猟によるものとしては, 重曹と緩衝液を加えて PH 7.5〜8.0とした活性 化 $2 \%$ グルタールアルデヒド溶液に 30 分〜 12 時 間, 有効塩素 $10,000 \mathrm{ppm}$ (約 $1 \%$ ) 次曲塩素酸
ソーダ溶液に $1 \sim 12$ 時間, $10 \%$ オルムアルデ ヒド溶液に30分〜 12時間などの浸漬方法のほか エチレンオキサイドガスが用いられる。これら の方法は，耐熱性のない被消毒物の消毒，熱処 理による隇菌または消毒の前処置としても利用 される，次車塩素酸剂は，金属類を腐蝕するの で金属の消毒には不適である，活性化グルタ一 ルアルデヒドは, ほとんど全ての医療器具, 器 材類の消毒に用いられる. 大量の血液が付着し た金属類で, 值ちにオートクレブなどの熱処置 不能の場合には，本溶液を用いた超音波洗浄器 で血液を落すか，本液内で洗浄，そのまま30分 〜数時間浸漬後水洗してオートクレーブなどの 熱処理すれば確実に減菌出来る，いずれにせよ これら次亜塩素酸剤，グルタールアルデヒド液 内に直接ある程度の時間手指を入れなければな らない場合は，皮膚への刺戟を避けるためゴム 手袋の着用が必要である.エチレンオキサイド では, 水分の存在下では滅菌効果の減弱をきた すと共に，B型肝炎ウィルスの滅菌には実用的 な面で多少疑問がある。

消毒剤の B 型肝炎ウィルスの感染性への影響 を検討した実験や研究報告は少ない。これは B 型肝炎が人，チンパンジー， rhesus monkey以 外では感染実験が出来ないことやウィルスの培 養が成功していないことなどによるものである. 更に感染性の消失したウィルスでも抗原性を保 有していることがあり，逆に感染性がありなが ら抗原性を消失している場合もあり， B 型肝炎 ウィルスの滅菌消毒法が細部にわたって明確に 確立されていない現状が，これらに起因してい る.上述したようにB型肝炎ウィルスの抗原性 の消失が感染性の消失を意味するわけではない が，その抗原性に対する消毒剤の影響を調べた 報告はみられる.著者らも次亜塩素酸ソーダ,グ ルタールアルデヒド, イルガサン,パュマ,クロ 一ルヘキシジンなどの消毒剂が， B 型肝炎ウィ ルスの抗原性に対する影響を R.I. A. 法によっ て検討をしてみた。 Radioimmunoassay (AUS RIA-II-125) で10,000 cpm $の \mathrm{HBs}$ 抗原陽性患 者血清々，精製 HBs 抗原（力洒 LAHA : 6400 倍）の20倍液（AUSRIA-II-125:9679cpm） をそれぞれ $0.2 \mathrm{ml}$ と各種各濃度の消毒剂 $0.2 \mathrm{ml}$ 
（20） 医器学 Vol. 50, No. 5 (1980)

を $5,15,30,60$ 秒間室温にて振䔽後, HBs 抗 原陰性血清で稀釈し， R. I. A. 法で測定した. 使用消毒剤の最高濃 度と AUSRIA-II-125 の Beeds $45^{\circ} \mathrm{C} 2$ 時間 incubate し, 次いで使用 したHBs 抗原陽性患者血清で测定し，これを 各種消毒剤作用前の測定值とし， cutoff value は negative control の2.1倍とした.

Fig. 1 は, HBs 抗原陽性患者血清の抗原性に 対して，有効塩素濃度 $1000 ， 5000 ， 10000 \mathrm{ppm}$ の次西塩素酸ソーダ溶液の影響をみたもので,

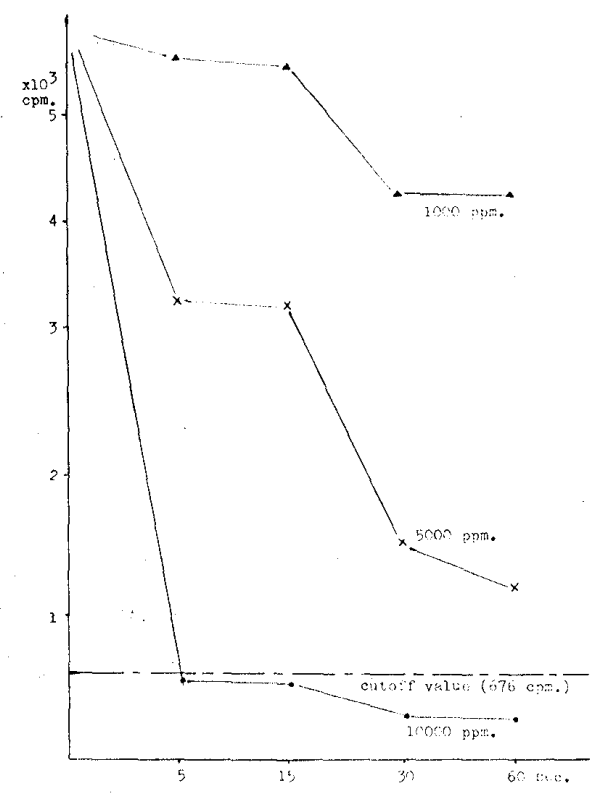

Fig. 1 Counts in HBAg positive serum mixed with hypochlorous sodium

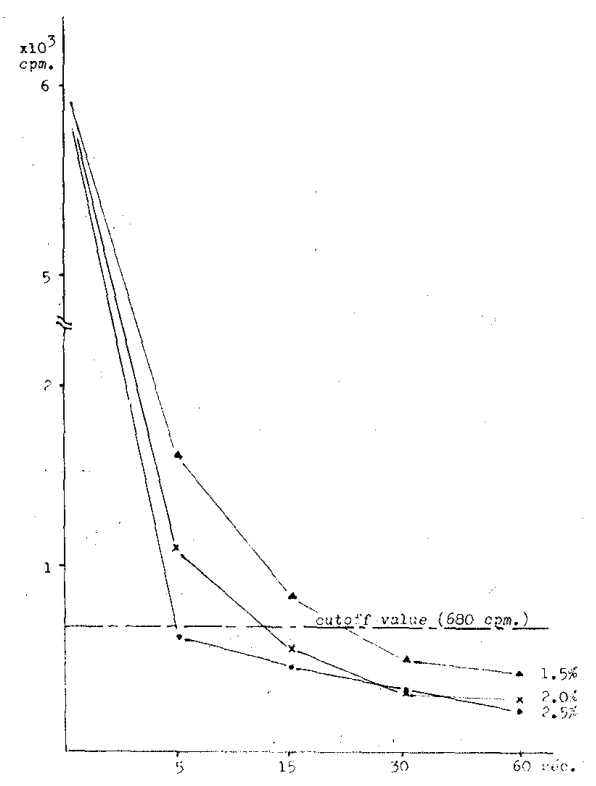

Fig. 2 Counts in HBAg positive serum mixed with glutaraldehyde

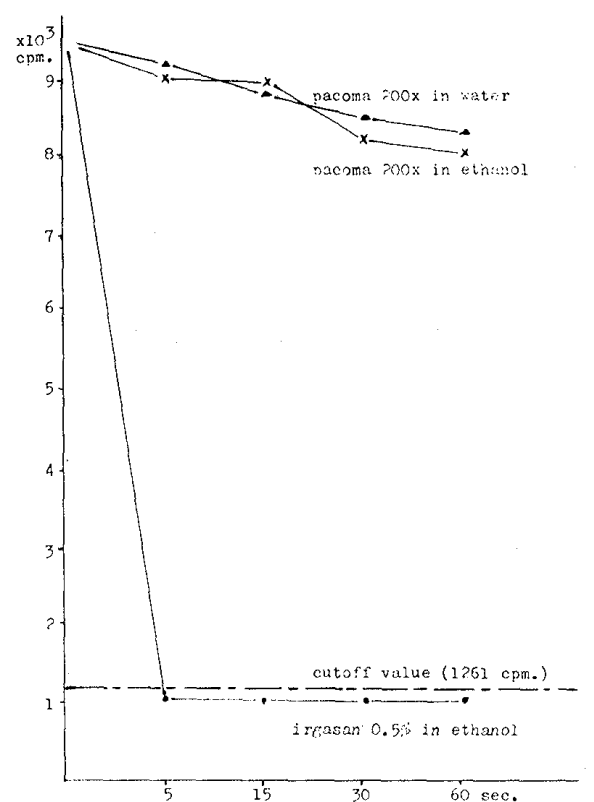

Fig. 3 Counts in purified HBAg mixed with pacoma and irgasan Dp-300.

$10000 \mathrm{ppm}$ 溶液 5 秒閒の接触で cutoff value 以 下になり，抗原性を消失させていると考えられ る. 同様に Fig. 2 はグルタールアルデヒドの 影響で， $2.5 \%$ 溶液で 5 秒， $2.0 \%$ で 15 秒， 1.5 \%で 30秒以上でいずれも cutoff value 以下で ある. Fig. 3 は，精製 HBs 抗原に対するパコ マ，イルガサンアルコールの影響を示したもの で，0.5\% イルガサンアルコールでは 5 秒間以 上で cutoff value 以下となった.これら一連 の実験結果をまとめたものが Table で，表中 (十）が cutoff value 以下で抗原性に影響を与 えたもので，(一) が cutoff value 以上で抗原 性に影響を与えなかったものを示している.

\section{IV 医療従事者への対策}

\section{IV-1 採用時の HBs 抗原, 抗体の 検查と定期検查}

医療従事者が $\mathrm{B}$ 型肝炎ウィルスに感染する危 険性は一般人より高く, 病院職員として新規採 用時と, 病院職員全体を対象として年 $1 \sim 2$ 回 の定期的な HBs 抗原, 抗体の検查を施行し， HBs 抗原陽性の場合は，自分の血液，体液など で周囲を污染しないよう注意し，個人衛生を守 らせ同時に専門医の指示をあおぐ。

昭和51年秋に調査した国立大学附属病院28施 設中 8 施設 $(28.6 \%)$ が HBs 抗原検查を施行し ており，抗体については 5 施設 $(17.9 \%)$ が施 
Table. Effect of drugs on counts in HBAg positive serum.

\begin{tabular}{|c|c|c|c|c|c|c|c|c|c|c|c|c|c|c|c|c|c|c|}
\hline $\begin{array}{r}\text { drugs } \\
\text { conc } \\
\text { rat }\end{array}$ & \multicolumn{3}{|c|}{$\begin{array}{c}\text { hypochlorous } \\
\text { sodium in water } \\
\text { (ppm.) } \\
1000500010000\end{array}$} & \multicolumn{3}{|c|}{ 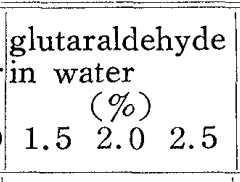 } & \multicolumn{3}{|c|}{$\begin{array}{l}\text { irgasan DP- } \\
300 \text { in ethanol } \\
(\%) \\
0.10 .30 .5\end{array}$} & \multicolumn{3}{|c|}{$\begin{array}{c}\text { pacoma } \\
\text { in water } \\
\text { (times) } \\
2005001000\end{array}$} & \multicolumn{3}{|c|}{$\begin{array}{c}\text { pacoma } \\
\text { in ethanol } \\
\text { (times) } \\
200 \quad 500 \quad 1000\end{array}$} & \multicolumn{3}{|c|}{$\begin{array}{c}\text { chlorhexizine } \\
\text { in ethanol } \\
(\%) \\
0.1 \quad 0.30 .5 \\
\end{array}$} \\
\hline 5 secon & - & - & + & - & - & + & - & - & - & - & - & - & - & - & - & - & - & 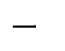 \\
\hline 15 seconds & - & - & + & - & + & + & - & - & - & - & - & - & - & - & - & - & - & - \\
\hline 30 seconds & - & - & + & + & + & + & - & - & - & - & - & - & - & - & - & - & - & - \\
\hline 60 seconds & - & - & + & + & + & + & - & - & - & - & - & - & - & - & - & - & - & - \\
\hline
\end{tabular}

- : cpm higher than the cutoff value. $+:$ cpm lower than the cutoff value.

行していた。これらの実施回数は，年 1 回が75 \%で他は不定期であった：翌52年秋の調查では， HBs 抗原について 31 施設中 20 施設 $(64.5 \%)$, 抗体についても14施設 $(45.2 \%)$ とその検查施 設が有意に増加し， $\mathrm{HB}_{\mathrm{e}}$ 抗原，抗体について も31施設中 2 施設 $(6.5 \%)$ で実施されていた。

職員 HBs 抗原の陽性率は，千葉大学付属病 院で，昭和50年より54年迄に定期的に検查した 結果が，1.0 2.5\%の間の数值を示し，抗体の 陽性率は，12.5〜24.4\%の間にあった。そのう ち昭和50年秋に実施した職員1083名の検查結果 を職種別にみると，HBs 抗原の陽性率 は医 師 $2.4 \%$ ，看護婦 $2.7 \%$ ，看護助手 $3.5 \%$ ，検查技 師 $3.0 \%$ ，その他 $2.2 \%$ で全体では $2.5 \%$ であっ た.このうち外科系看護婦の $3.8 \%$ ，外科系看 護助手の $5.6 \%$ は高率であったが，統計的には 有意でなかった。抗体の陽性率は，全体として $24.4 \%$ で，医師 $23.7 \%$ ，看護婦 $31.0 \%$ ，検査技 師36.4\%であった. 特に外科系医師, 看護婦, 検查技師が有意に高率で，最も感染の危険度が 高いことが推定された。

\section{IV-2 医療従事者への濃厚污染,} 感染が疑われたときの対策

感染の危険性のある刺創などでは，創傷部位 を直ちに強次亜塩素酸ソーダ溶液の綿球で拭き， 水洗後一般創傷処置をする.他方受傷者の HBs 抗原, 抗体を直ちに検查し, 抗原抗体共に検出 されない場合は，HBs 免疫グロブリンを受傷 後48時間以内に使用寸る. HBs 抗原陽性の場 合に上記グロブリンの投与は禁忌であり，抗原 陽性あるいは抗体陽性の場合はそのまま経過を 観察する．上述いずれの場合も，定期的肝機能 検查と注意深い経過観察が大切である.

\section{$\mathrm{V} \quad$ 感染管理の組織化と衛生管理}

単にB型肝炎感染だけでなく，院内感染は医 療上はもち万ん病院管理上からも，人道的な面 からも問題であり，病院全体として一貫した感 染管理の組織化と衛生管理が必要である。この ためには，院内感染対策委員会を設置し，その 重要な一部門としてB型肝炎ウィルス感染対策 実施計画の立案と実行，院内感染発生時にはそ の発生原因, 実態の調查と把握並びにその報告 と対策を行なう。他方医療従事者の健康調查や 管理と，職員への院内感染に対する教育やその 計画を企画することが必要である.

$\mathrm{B}$ 型肝炎感染防止対策は，院内感染問題の一 つの重要な課題であるが，これまで述べたよう に，滅菌消毒法をとり上げても細かい点では明 確に確立されていない上に，保険診療報酬上 でも $\mathrm{HBs}$ 抗原検査料のみが認められ， $\mathrm{HBs}$ 抗 体, $\mathrm{HBe}$ 抗原抗体の検查料は未承認である. 各医療施設間の検查方法や内容の差，滅菌消毒 施設設備の差などがあって一概にその対策，手 段を明確に断定することは出来ない，ただきめ の細かい，各それぞれの施設に適した基本的感 染予防対策をたて，それを着実に実施すること により，可成りの予防効果を上げること出来 る。

注）本論文は，昭和55年 3 月 1 日，東京で開催され た第48回滅菌法研究会に抢ける講演要旨である. （編集部） 